\title{
6 Too Much Rushdie, Not Enough Romance? The UK Publishing Industry and BME
(Black Minority Ethnic) Readership
}

\author{
Claire Squires
}

The UK publishing industry in the twenty-first century is one populated by high-profile, multicultural authors. Monica Ali, Hari Kunzru, Andrea Levy and Zadie Smith have enjoyed critical and commercial success, building on the literary and marketplace achievements of postcolonial writers such as Salman Rushdie, Ben Okri and Arundhati Roy. Postcolonial and multicultural writers, and novels with multicultural characters and with postcolonial themes, have been foregrounded by the mechanisms of the industry: its marketing activities; its literary awards; and by the literary media. Yet how does the British publishing industry cater for multicultural consumers, or, in the acronym predominantly used in official UK discourse, a BME (Black Minority Ethnic) readership?' Using industry data and surveys, this chapter explores this question with regards to content, genre and access to reading material, and analyses how the operation of the book trade, and demographics of industry workers, might affect readership. It also considers whether the visibility of multicultural literary authors has inflected the production and consumption of works towards an exoticising mode which, it is argued, does not encompass diversity of writing and reading practices, including in terms of genre.

The framework adopted in this chapter draws on Robert Darnton's book communications circuit, with its organising principles of agents within that circuit (including authors, publishers, printers, booksellers and readers), and the impact of the "economic and social conjuncture" in which the circuit is embedded (Darnton 1990). It also draws on revisions to his "model circuit" by those who have sought to politicise and foreground the gatekeeping role of publishers, such as Simone Murray's call for a "rewiring" of the communications circuit in Mixed Media: Feminist Presses and Publishing Politics (2004, 13).

In the communications circuit of the contemporary British literary marketplace, BME authors have been highly visible, as well as commercially and critically successful. Zadie Smith's White Teeth (2000) is a case in point: with a black Jamaican mother and a white English father, a childhood spent in multicultural northwest London, and a very recently completed degree in English literature from Cambridge, Smith was a highly promotable author, endorsed by Rushdie himself (Squires 2002; Smith 2000, front cover).

Copyright 2012 From Postcolonial Audiences: Readers, Viewers, Reception

edited by James Procter, Bethan Benwell, and Gemma Robinson. Reproduced

by permission of Taylor and Francis Group, LLC, a division of Informa plc. 
Journalists self-reflexively referred to her marketability, with the Daily Telegraph describing her as "the perfect package for a literary marketing exercise", and the Guardian commenting, with some knowingness, that "she ha[s] the fortune, or misfortune, to be the perfect demographic" (Wallace 2000, 18; Hattenstone 2000, 7). The novel's success built on Smith as a promotable young author, and the themes and content of the book itself, but also upon external factors. Not the least of these was the visibility of postcolonial novelists as both shortlistees and winners of the Booker Prize, and the consequent market focus the UK's highest-profile literary award has brought to postcolonial and multicultural writers and their works.

Narratives surrounding the Booker Prize, produced by those connected to the award and the broader commentary of literary journalists and critics, have emphasised Booker's role in foregrounding, promoting and celebrating diasporic writers, including Rushdie, Ben Okri and Arundhati Roy (winners in 1981, 1991 and 1997). There is an aspect of mutual celebration in these narratives, in which the prestige bestowed on writers reflects back to the Booker, which then represents itself as progressive in its consecration of nonwhite and/or postcolonial writers (white writers from postcolonial nations, including Margaret Atwood, Peter Carey and J. M. Coetzee are also brought into these narratives) (Todd 1996; Niven 1998; Huggan 2001; Squires 2004; English 2005; Ponzanesi 2006). These Booker Prize-winners, and subsequent celebrated writers of the 2000s, including Smith, Ali, Kunzru and Levy, might well be thought to denote a publishing industry receptive to and appreciative of writers of colour and works featuring multicultural characters and themes. However, while representing a diversity of author biography and novelistic theme, these writers broadly fall into one particular category in the publishing marketplace: that of literary fiction.

Defining "literary fiction" is a complex process, although a convenient shorthand can be found. Industrially, literary fiction can be defined in two ways: by a process of negation; and contextually. The former process, explained by Steven Connor, would suggest that literary fiction is "not formula fiction or genre fiction, not mass-market or bestselling fiction-and, by subtraction, it is what is left once most of the conditions that obtain in contemporary publishing are removed" $(1996,19)$. In Marketing Literature (2007a), I argue that market conditions apply to literary as well as mass-market fiction. Connor's formal definition is still useful, though, and the generic divisions to which it refers are used in the contextual definitions of the publishing industry. Literary fiction is that published by literary imprints and companies (e.g., Jonathan Cape, Faber and Faber, Picador and Sceptre), packaged and formatted in certain ways to look "literary", and entered for the more "literary" of book awards, such as Booker. Such a definition is circular, and it does not fully explain how agents within and surrounding the communications circuit (e.g., publishers, literary agents, the media, academics) construct the categories by which fiction is classified, and how this is a dynamic, negotiated process. 
Nonetheless, it offers a broad view of the processes by which marketplace categories are constructed. For the purposes of this chapter, it is sufficient to acknowledge that constructions of literary genre pertain strongly within the publishing industry, and are actively used in the marketing of books.

The question of genre and definitions of literary/other types of fiction is relevant to an analysis of BME readership. Literary fiction by multicultural writers, and with multicultural themes and characters, has undoubtedly been critically and commercially successful at the turn of the twentieth and twenty-first centuries in the UK and in the broader English-language speaking markets to which the British industry exports. But is such success appreciated by a British BME readership? Does it necessarily cater to its tastes, as far as these "tastes" can be discerned or grouped? And-from a commercial perspective-is it the most effective form of publishing to reach the pockets of a BME readership? Or, as the title of this chapter asks, is this a case of too much Rushdie and not enough romance; an over-emphasis on the literary novel and an undervaluation of mass-market fiction?

Two surveys of multicultural readers conducted at the end of the first decade of the twenty-first century refer in some detail to questions of genre. The first, Getting Closer to the BME Bookmarket (a collaboration between the publisher HarperCollins, The Reading Agency (TRA), an independent charity which promotes reading in the UK, and The Bookseller), was published in 2008; the second, from 2010, was conducted on behalf of the DSC South Asian Literary Festival (SALF), also in association with The Bookseller. Both surveys operated a consumer survey methodology with substantial sample sizes in order to examine reading, book buying and borrowing behaviour and attitudes, using ethnic demographic categories, premised on the hypothesis that the publishing industry could cater more effectively for a diverse readership. Getting Closer compared a self-designated BME reader sample to a separate, general reader (i.e., an overall population with no ethnic breakdown) sample. The SALF survey focused on readers who designated themselves as Asian/British Asian, in the context of an overall population, other ethnic designations, and (for the purposes of the headline report) a White: British sample.

Getting Closer, while asserting that no simplistic link exists between BME authorship, content and readership (identifying that the "most frequent reading choices for BME readers are the bestsellers that are popular across the board" (Hicks and Hunt 2008, 38)), suggested that publishers were failing to provide adequately for, or understand, BME readers in the UK. This failure derives in part from the marketplace successes of literary BME authors (a genre which has a strong appeal to non-BME readers), and neglecting other market sectors including some types of mass-market fiction and memoirs (Hicks and Hunt 2008, 38). With regards to fiction, although the BME and general population both demonstrated the highest preference for crime and thrillers, compared to the general population, BME readers showed a greater 
liking for romance, whereas literary fiction was less widely read. However, romance and literary fiction were equally popular among BME respondents, each being read by 26 percent (Hicks and Hunt 2008, 12). The point, therefore, is the difference between the BME and general panel, not that BME readers prefer romance to literary fiction.

With non-fiction, a high proportion of respondents (39 percent) had read "true life stories", which the report glosses as "inspirational memoirs" (Hicks and Hunt 2008, 12). When all respondents were asked to name the title they had most recently read, the general panel's list showed a preference for literary authors (Levy, Smith, Ali, Chimamanda Ngozi Adichie). The BME list accentuated "stories that reflect real life set in the UK", including Constance Briscoe's memoir Ugly (2006), which documents an abusive childhood before her rise as a black female barrister and judge (Hicks and Hunt 2008, 24). This book was mentioned seven times by BME readers, but not at all by the general panel.

The SALF report had some analogous findings. The survey asked its respondents about genres that they liked to read (with respondents being able to cite as many genres as they wanted), rather than ones they had actually read. A range of demographic data (including age and gender as well as ethnicity) was recorded, but the report focused on a comparison between the South Asian and White: British population (indicating an assumption that the UK publishing industry is structured around the reading patterns of white readers; for the purposes of this discussion, the total sample responses have also been included). There were distinct differences between the South Asian, White: British and total population respondents in terms of the preference for fiction genres: crime/thriller (33/75/69 percent respectively); classic "i.e. pre-C20th" (50/64/63 percent); historical (39/56/54 percent); science fiction/fantasy (24/36/35 percent); and poetry/plays (29/22/24 percent), with the latter being the only genre that the South Asian readership liked more than the White: British and total readership. Figures for literary (56/62/63 percent) and romance/love stories (31/32/31 percent) were more similar. Overall, the fiction genres had (apart from the poetry/plays category) higher preference among the White: British and overall respondents than the South Asians (DSC South Asian Literature Festival UK Readers' Survey 2010, Volume $1,8)$. Further figures from the SALF survey reveal striking differences in terms of the non-fiction genres: auto/biography/memoir, travel and humour had similar figures, but a disparity arises between South Asians, White: British and the total population with self-help/motivational (43/13/18 percent respectively); religious/spiritual (52/12/17 percent); and politics (29/12/15 percent). South Asian readers, as the authors of the report commented, generally expressed a much greater liking for, and readership of, non-fiction than the White: British group (DSC South Asian Literature Festival UK Readers Survey 2010, Volume 1, 7-8).

The SALF survey went on to investigate attitudes towards books with "South Asian influences, characters, subjects or settings, and which are 
written in or translated into English" (2010, Volume 1 Summary Report 2). These questions produced a shift in preferred genres for the overall population, with crime/thriller dropping from the top spot to sixth, behind (in order of preference) literary fiction, historical fiction, classic fiction, travel and history. Moreover, when the South Asian respondents were asked whether they would read more books with a "South Asian influence" if they were available, responses showed that there would be preferences for the categories of literary fiction, religious/spiritual, historical and auto/biography. As the report comments, "only $2 \%$ of relevant [i.e., South Asian] respondents felt there were sufficient books already" with a "South Asian influence" (DSC South Asian Literature Festival UK Readers' Survey 2010, Volume 1, 14-16). The survey also probed attitudes towards the children's book sector, with respondents voicing a clear demand for children's books with a South Asian influence: 46 percent of the total wanting more, 38 percent of White: British, and 89 percent of South Asians (DSC South Asian Literature Festival UK Readers'Survey 2010, Volume 1, 17).

Both these industry reports, and discussion at events such as the 'Discovering Britain's Biggest Untapped Market-Muslim Focus' seminar at the 2010 London Book Fair (which included a discussion of genres seemingly less favoured by Muslim writers but wanted by Muslim readers, including children's books and mass-market fiction), demonstrate a mismatch between the production of books (be it by authors or publishers), and the desires of consumers. The data from the two surveys demonstrates key discrepancies (the difference between the strong BME liking for crime fiction in the 2008 survey, for example, compared to its lesser appeal to the more narrowly defined segment of South Asians in 2010). The evidence they provide, therefore, only begins to hint at a full understanding of the nuances of demographics with relation to $\mathrm{BME}$ readership (with those demographics broadening to include gender, age, social class, educational level). Claire Chambers, one of the speakers at the 2010 London Book Fair seminar, discusses in her article "Multi-Culti Nancy Mitfords and Halal Novelists: The Politics of Marketing Muslim Writers in the UK" (2010) the addition of the category of faith (particularly in terms of Islam) into the demographic discussions of writing, publishing and reading. A discussion of a unified BME "segment" is in itself, therefore, a misapprehension of the diversity of groupings of non-white readers, and both surveys make normative assumptions about reader behaviour: both of BME groupings and sub-groupings, and the "general" and/or "White: British" population to which they are compared. However, while normative assumptions should be questioned, not least if it is assumed that the "White: British" population is the norm, such groupings are central to the methods of action research, are the foundation of marketing, and also underpin the attempt to analyse the political role of gatekeeping on the publishing industry.

Analysing the relationship between writers, content and readers is a highly complex process, which is still rarely done in trade publishing, although it 
is crucial to an informed consideration of segmentation strategies (Squires 2007b). Moreover, as Getting Closer itself states, "What will not work is to simplistically assume that the BME tag will connect the BME book up to the BME reader" (Hicks and Hunt 2008, 38). Nonetheless, an accompanying Bookseller article to the SALF survey, which begins with a brief overview of the successes of South Asian writers, not least in terms of book awards, attempts to draw some conclusions about South Asian readers. Asking whether the UK publishing industry is "reaching out to this growing demographic", Tom Tivnan concluded that, based on the evidence in the survey, "The answer may be that the industry is not doing enough to attract South Asian readers and that there is a need to have more books geared towards the South Asian community. Perhaps publishers are missing out on an untapped market?" (Tivnan 2010).

The challenge of the "untapped market" is a commercial one, configured in the language of market segmentation and expansion: the managing director of Waterstone's (the UK's biggest high-street bookseller) demonstrated his eagerness to see the detailed survey results (Denny 2010). The SALF survey additionally asked its respondents about barriers to buying or reading more books with a South Asian influence. Eighty-nine percent of the Asian/British Asian sample surveyed said there were barriers compared to only 23/13 percent of the total and White: British sample (such books being "not easy to find in bookshops, even where they are available"; "bookshops don't stock them"; they are "not readily available in libraries" or "schools"; and potential readers "cannot find them easily on the internet") (DSC South Asian Literature Festival UK Readers' Survey 2010, Volume 1, 19). Other questions in both surveys probed habits and attitudes with regards to bookshops, touching on the question of where and how books with BME and/or South Asian influence should be shelved and promoted, offering some specific channels of investigation for booksellers stocking books for the "untapped market".

The motivation behind both surveys, however, went beyond commercial expansion of the market, incorporating an interest in how reading habits could be inculcated and enhanced. Getting Closer provided recommendations to the public library system about support for BME readers, and the promotion of books by BME writers and/or with BME content. These recommendations were coupled with previous research conducted by The Reading Agency, in which Public Lending Right (PLR) figures demonstrated the key role libraries have in "growing the market for BME writing" (Hicks and Hunt 2008, 40). TRA is an advocate for the role of libraries in promoting areas of "specialist interest" (which is, according to its own evidence, underrepresented in mainstream publishing and/or less commercially viable) and in reader development (which has alternate drivers to those of the commercial publishing industry). Yet TRA worked in cooperation with one of the conglomerate publishers for its survey, showing that different drivers in the promotion of BME books and support for BME readers can work in effective 
partnership. However, the public library system and the non-commercial promotion of books, reading and literacy have a particular role to play, which, in working for and with groups often less effectively catered for by the mainstream commercial publishers, is ideologically motivated. The announcement of swathing funding cuts to public libraries and reader development agencies such as Booktrust and the National Literacy Trust (NLT) under the UK government's Comprehensive Spending Review and via local councils at the end of 2010 and beginning of 2011 caused outcry, not least because they threatened the balance between private and public partnerships in the world of books and reading. The impact of such cuts is that one of the key modes of transmission of information, education and culture risks being left predominantly to commercial organisations, which, in addition to privileging the mainstream, are by their nature subject to "market censorship", in André Schiffrin's terminology from The Business of Books (2000, 103-28). Schiffrin's subsequent book Words and Money (2010) makes an impassioned plea for the role of public money in cultural production and consumption. His broader argument about state and philanthropic intervention can be applied to the BME book market.

The active promotion of reading, with an underpinning ideology of combating social exclusion, was a key strand of UK government policy in the 1990s and 2000s, frequently operating via private and public partnership funding models. Campaigns such as the NLT's Reading Champions and Reading the Game enlisted the aid of "Premier League Reading Stars" for school visits, and produced a variety of promotional materials, such as a 2009 poster campaign featuring footballers Rio Ferdinand, Ashley Cole, David James and Alan Smith. The primary demographic target for these NLT campaigns was boys generally, but using sports stars enabled a high proportion of BME reading advocates-three out of four of the 2009 poster stars, for example. Diversity of genre was emphasised in the "Reading the Game Movie" (a promotional video in sports programme style) in which footballers talked about their reading habits: their favourite childhood story books, but also their current reading habits of newspapers, magazines and in particular auto/biographies ("Reading Champions"; "Reading the Game"; "Champions Read"; "RTG"). Genre diversity and a concern to find the right reading materials for individuals and communities link to NLT research in which young people's self-perceptions as readers found its respondents had seemingly internalised perceived literary hierarchies, so that the term "reader" was closely associated with reading fiction or poetry. Unless they regularly read these genres, many of the young people surveyed did not designate themselves as "readers", even if they regularly read newspapers and magazines (Clark, Osborne and Akerman 2008; cited in Squires 2009). This survey did not explore BME demographics, but its findings around the perceived valorisation of some genres (here by gatekeeping teachers and librarians) over others connect to the issues surrounding genre in the BME market. 
This survey evidence hints at the ways in which genre hierarchies are produced, mediated by a variety of gatekeepers and (with degrees of resistance or acceptance) received in the contemporary communications circuit. All agents in the circuit begin as readers, but their varying positions-as commissioning editors, literary reviewers, teachers, librarians-combine to effectuate patterns of literary and demographic stereotyping. Such stereotyping forms the basis of market segmentation, but this can be altered by commercial, sociological, cultural and, as Chambers (2010) describes, political perspectives. Chambers draws on the work of John K. Young, who makes the argument in Black Writers, White Publishers: Marketplace Politics in Twentieth-Century African American Literature (2006) that "an editorial emphasis on race raises important questions about who editors are. It hardly seems coincidental that a field that has been populated primarily by white men has focused its energies primarily on white, male authors" (32). His argument holds true in an interrogation of the twenty-first-century British market, in which various initiatives have demonstrated, and attempted to act upon, the gatekeeping role of the publisher: a "rewiring" of the communications circuit, in Murray's terminology.

Chambers traces this contestation of "editorial emphasis" through the Arts Council England (ACE)'s decibel programme, which began with a survey of diversity in the publishing workforce. 'In Full Colour: Cultural Diversity in Book Publishing Today' noted that only 13 percent of its respondents from the UK publishing industry were from black or Asian backgrounds (Kean 2004a). This statistic was greater than the UK population as a whole (cited from census data as 8 percent), but-given that publishing is principally based in London (where almost 80 percent of respondents were based)-it did not match the BME population of London (almost 30 percent). Moreover, the industry respondents themselves perceived that publishing had a homogenised white, middle-class and even Oxbridge-dominated workforce, one in which BME workers had "experiences of institutionalised racism, tokenism and insensitivity" (Kean 2004a; 2004b; 2005, 36). The specific warning made by the report was that this homogenous workforce meant that publishing was not allowing itself access to a "share of the $£ 32 \mathrm{bn}$ spending power of Britain's minority ethnic communities" (Kean 2004b, 5). By not admitting enough individuals from BME backgrounds into gatekeeping positions in the communications circuit, the report argues, the industry was not creating sufficient expertise to capitalise on all potential demographic market segments.

Following 'In Full Colour', various initiatives were set up to diversify the gatekeeping role. DipNet (the Diversity in Publishing Network) was established in 2005 to provide a support network for BMEs already in, or wishing to enter, the publishing industry. ACE sponsored bursaries for BME interns at a number of publishing companies; workshops were held where unpublished BME writers could meet with publishers (Kean 2005). A draft 'UK Publishing Equalities Charter', a collaboration between ACE, DipNet, the 
Independent Publishers Guild (IPG), the Publishers Association (PA), Skillset and the Society of Young Publishers (SYP), was launched in 2010 with the aim of helping "promote equality and diversity across UK publishing and bookselling, by driving forward change and increasing access to opportunities within the industry" (UK Publishing Equalities Charter Supplementary Information Q\&A Consultation Phase II 2010).

Chambers traces this history of the publishing workforce in specific relation to the publishing, marketing and reception of British Muslim writers. Despite seeing a largely positive trend for increasing access to non-white industry workers and openness to non-white authors, Chambers identifies (pace Graham Huggan's argument in The Postcolonial Exotic (2001) that the marketing activities of metropolitan publishing industries exoticise non-white authors and their books) an anthropologically stereotyped commodification of British Muslim writers in the twenty-first century, one which, moreover, tends to focus on literary fiction rather than other genres. The article 'Still Not in Full Colour', written by Kean four years after 'In Full Colour', and in response to 2008's Getting Closer report, substantiates Chambers's claim about genre and anthropological commodification. At the seminar launching Getting Closer, HarperCollins's managing director apparently commented that "Publishers must act like cultural tourists to find mass appeal products and look beyond the literary genre [ ...] We need to source and encourage new voices" (Barnicoat 2007,6). While not contesting the comment about literary genre, Kean responded that, “tourism' is the wrong simile: a 'tourist' is not the same as someone with roots in a market. Tourist publishers trying to 'get down with the locals' risk being the publishing equivalent of Ali G: fake, laughable, patronising and ultimately mistaken in their assessment of what a market wants" (Kean 2008). Kean is also sensitive to tokenism in bringing in BME commissioning editors and other book-trade gatekeepers as native informants on their cultures or readership communities, particularly in order to commercialise opportunities relating to them. Her article 'A Year in Diversity' featured several BME writers and publishers commenting on white publishers enforcing-knowingly or otherwise-a narrow "spectrum of writing": white publishers still tied up in a "colonial attitude"; as "reluctant to consider books by black authors that deal with anything other than race as a central theme"; with a "preference for books that highlight the white experience of minority ethnic culture"; and as "looking for a certain type of writing and if your writing doesn't hit that market they are not interested" (Kean 2005, 36-37).

Publishing initiatives from within the BME community have sought to respond to and overcome this lack of representation, tokenism and the role of the native informant. Just as Virago and other feminist book trade organisations of the 1970s and 1980s strove to increase access at every point in the book communications circuit (women as writers, publishers, booksellers and readers, and as subject matter) (Murray 2004), so a variety of companies have 
sought to open the British book market to BME participation and content. In 'Material Factors Affecting the Publication of Black British Fiction' (2010), Philippa Ireland traces this post-war history, referring both to established companies (such as Allan Wingate, Chatto \& Windus, Jonathan Cape and Faber \& Faber) publishing black British writers, and the foundation of "pioneering black publishers" in the late 1960s (New Beacon Books and Bogle L'Ouverture) and, with the establishment of the X Press in 1992, a more mass-market, even "sensationalist" approach to the fiction market (2010) $(142,159,162)$. In the children's market, Tamarind began to produce multicultural books for children and schools in 1987, following founder Verna Wilkins's experience of seeing her black son depict himself, for the cover of a booklet he was making at school, with a "bright pink face". Her impetus to become a writer and publisher developed from that of the parent and reader, with the purpose of "redress[ing] the balance in publishing", focusing on the children's market (Wilkins 2008). Initiatives aimed at promoting diversity in the twenty-first century also include book prizes: the Diverse Voices Award, and the Commonword Children's Diversity Writing Prize ("Frances Lincoln" 2011; "Press Release" 2010). Urbantopia, another children's publisher, was established in 2010 in specific response to Getting Closer's call to "address the lack of diversity and representation" and to "source and encourage new voices" ("Birth").

Such initiatives developing BME writing, publishing and reading demonstrate awareness of, and positive action to change, the relationship between various agents in the communications field, including the gatekeeping role of the publisher and others such as literary prize judges. However, the UK book publishing industry has some distance to go before it can claim to be catering effectively for a BME readership, whether in commercial, cultural or political terms. There is still much to be done to establish professionalised readers within the book communications circuit- in other words, BME industry workers. There is not a simple correlation, however, between having BME agents in significant positions in the publishing industry, and the encouragement of, and effective provision for, multiple BME readerships, without falling into the traps of tokenism, exoticisation and normative assumptions. And yet, if BME readers are to be effectively catered for-commercially, culturally or politically-it is clear that the industry needs to consider carefully, and act on, issues of diversity in its workforce. It must also have a diversified approach to the provision of reading matter, and seek to redefine attitudes to genre.

An examination of issues relating to BME readerships demonstrates how the critical and commercial successes of postcolonial literary writers has operated alongside-even perhaps inflected-the publishing of non-white writers away from other genres, some of which have been shown to be of particular appeal to BME readers. The relationship between readers, writers and publishers (and other book-trade gatekeepers such as literary agents, 
booksellers, librarians and literary prize judges) structures the production and reception of the publishing industry. An interrogation of aspects of this relationship would seem to suggest that, although positive action is underway in a variety of initiatives, positions of power in the communications circuit are still having a negative impact on BME readers. Analysis of BME readership and literary consumption, as well as the demographics of publishers, writers and the contents of their books, leads therefore to a set of key questions about literary production. Only by asking these questions, and acting upon the answers, will a properly diversified publishing industry be enabled.

\section{Notes}

1. Precise definitions and derivations of BME vary and exist only in draft form for the OED ("of or designating members of black and ethnic minority (esp. South Asian) communities in the United Kingdom"). The UK Census has collected data on ethnicity since 1991, with categorisation self-assigned by respondents. Oxford English Dictionary, "Draft Additions September 2008", http://www. oed.com.ezproxy.stir.ac.uk/view/Entry/14168? redirectedFrom=bme\# eid12804 2566, accessed June 26, 2011.

\section{References}

Barnicoat, Laura. 2007. "BME Readers Demand Diversity." The Bookseller, November 30, 6(5309). "The Birth of Urbantopia." n.d. Urbantopia. http://www.urbantopia.co.uk/about-us.html.

Briscoe, Constance. 2006. Ugly. London: Hodder \& Stoughton.

Chambers, Claire. 2010. "Multi-Culti Nancy Mitfords and Halal Novelists: The Politics of Marketing Muslim Writers in the UK." Textus 23: 389-404.

"Champions Read." n.d. National Literacy Trust. http://www.literacytrust.org.uk/ assets/0000/2969/footieposters.pdf.

Clark, Christina, Sarah Osborne and Rodie Akerman. 2008. Young People's SelfPerceptions as Readers: An Investigation Including Family, Peer and School Influences. National Literacy Trust, January. London (or url http://www.literacytrust.org.uk/ assets/0000/0558/Self-perceptions_as_readers_2008.pdf)

Connor, Steven. 1996. The English Novel in History 1950-1995. London: Routledge.

Darnton, Robert. 1990. "What Is the History of Books?" In The Kiss of Lamourette: Reflections in Cultural History. London: Faber and Faber. First published in Daedalus 11(3): 65-83.

Denny, Neill. 2010. "South Asians Less Likely to Use Chains." The Bookseller, November 26. http://www.thebookseller.com/news/136094-south-asians-less-likely-touse-chains.html.

DSC South Asian Literature Festival, in association with The Bookseller. 2010. DSC South Asian Literature Festival UK Readers' Survey. London: BML.

English, James. 2005. The Economy of Prestige: Prizes, Awards, and the Circulation of Cultural Value. Cambridge: Harvard University Press.

“The Frances Lincoln Diverse Writers Award 2011.” 2011. Seven Stories. http://www. sevenstories.org.uk/learning/projects/the-frances-lincoln-diverse-voices-award2011-p327. 
Hattenstone, Simon. 2000. "White Knuckle Ride." Guardian, December 11, G2 section, 6-7.

Headley, Victor. 1992. Yardie. London: X Press.

Hicks, Debbie, and Catherine Hunt. 2008. Getting Closer to the BME Bookmarket: Detailed Research Findings. HarperCollins and The Reading Agency.

Huggan, Graham. 2001. The Postcolonial Exotic: Marketing the Margins. London: Routledge.

Ireland, Philippa. 2010. "Material Factors Affecting the Publication of Black British Fiction." PhD diss., The Open University.

Kean, Danuta. 2004a. "In Full Colour: Cultural Diversity in Book Publishing Today." London: Bookseller Publications.

- 2004b. "Diversify or Die, Warns Report." The Bookseller, March 12, 5.

- 2005. "A Year in Diversity." The Bookseller, March 11, 36-37.

- 2008. "Still Not in Full Colour." Danuta Kean. http://www.danutakean.com/ blog/?p=305 (first published in The Author, Spring 2008).

Murray, Simone. 2004. Mixed Media: Feminist Presses and Publishing Politics. London: Pluto Press.

Niven, Alistair. 1998. "A Common Wealth of Talent." In Booker 30. A Celebration of the Booker Prize for Fiction. 1969-1998, 40-42. London: Booker.

Ponzanesi, Sandra. 2006. "Boutique Postcolonialism: Literary Awards, Cultural Value and the Canon." In Fiction and Literary Prizes in Great Britain, edited by Wolfgang Görtschacher and Holger Klein in association with Claire Squires, 110-37. Vienna: Praesens Verlag.

"Press Release: Partnership and Prize to Encourage Diversity in Children's Fiction.” 2010. Commonword. http://www.cultureword.org.uk/wp-content/ uploads/2011/01/Commonword-Childrens-Diversity-Prize.pdf.

"Reading Champions." n.d. National Literacy Trust. http://www.literacytrust.org.uk/ reading_champions.

"Reading the Game." n.d. National Literacy Trust. http://www.literacytrust.org.uk/ reading_the_game.

"RTG The Movie." n.d. National Literacy Trust. http://www.veoh.com/browse/videos/category/sports/watch/v181058412ydRwh7c.

Schiffrin, André. 2000. The Business of Books: How International Conglomerates Took Over Publishing and Changed the Way We Read. London: Verso.

- 2010. Words and Money. London: Verso.

Smith, Zadie. 2000. White Teeth. London: Hamish Hamilton.

Squires, Claire. 2002. Zadie Smith's White Teeth: A Reader's Guide. London: Continuum.

. 2004. "A Common Ground? Book Prize Culture in Europe." Jarnost The

Public 11(4): 37-47.

- 2007a. Marketing Literature: The Making of Contemporary Writing in Britain. Basingstoke: Palgrave Macmillan.

- 2007b. "The Global Market 1970-2000: Consumers." In A Companion to the History of the Book, edited by Simon Eliot and Jonathan Rose, 406-18. Oxford: Blackwell Publishing.

- 2009. "Marketing at the Millennium." In Children's Literature: Approaches and Territories, edited by Janet Maybin and Nicola J. Watson, 183-98. Basingstoke: Palgrave Macmillan.

Tivnan, Tom. 2010. "An Untapped Market." The Bookseller, November 26. http:// www.thebookseller.com/in-depth/feature/136096-an-untapped-market.html.

Todd, Richard. 1996. Consuming Fictions: The Booker Prize and Fiction in Britain Today. London: Bloomsbury. 
UK Publishing Equalities Charter Supplementary Information Q\&A Consultation Phase II. 2010. http://www.dipnet.org.uk/

Wallace, Sam. 2000. “Cutting Her Teeth with a Book Deal.” Daily Telegraph, January $15,18$.

Wilkins, Verna. 2008. "The Right to Be Seen.” Tamarind Books. http://www.tamarindbooks.co.uk/downloads/tamarind_righttobeseen.pdf.

Young, John K. 2006. Black Writers, White Publishers: Marketplace Politics in TwentiethCentury African American Literature. Jackson: University Press of Mississippi. 